\title{
Correction to: MHD turbulence
}

\section{Andrey Beresnyak ${ }^{1}$}

Published online: 8 June 2020

(C) The Author(s) 2020

\section{Correction to: Living Reviews in Computational Astrophysics (2019) 5:2 https://doi.org/10.1007/s41115-019-0005-8}

The publication of this article unfortunately contained a mistake. The acknowledgement is missing, you can find it below.

\section{Acknowledgements}

AB was supported by NASA Astrophysics Theory Program, Grant 80HQTR18T0065, and by basic research funds of the CNR.

Open Access This article is licensed under a Creative Commons Attribution 4.0 International License, which permits use, sharing, adaptation, distribution and reproduction in any medium or format, as long as you give appropriate credit to the original author(s) and the source, provide a link to the Creative Commons licence, and indicate if changes were made. The images or other third party material in this article are included in the article's Creative Commons licence, unless indicated otherwise in a credit line to the material. If material is not included in the article's Creative Commons licence and your intended use is not permitted by statutory regulation or exceeds the permitted use, you will need to obtain permission directly from the copyright holder. To view a copy of this licence, visit http:// creativecommons.org/licenses/by/4.0/.

Publisher's Note Springer Nature remains neutral with regard to jurisdictional claims in published maps and institutional affiliations.

The original article can be found online at https://doi.org/10.1007/s41115-019-0005-8.

Andrey Beresnyak

andrey.at.astro@gmail.com

1 Plasma Physics Division, U.S. Naval Research Laboratory, Washington, DC, USA 